УДК 349.23

DOI https:// doi.org/10.32837/yuv.v0i2.1720

М. Кузнецова,

кандидат юридичних наук, доцент,

завідувач кафедри приватного та соціального права

Сумського національного аграрного університету

\title{
АКТУАЛЬНІ ПИТАННЯ УКЛАДЕННЯ ТРУДОВОГО ДОГОВОРУ 3 ПРАЦІВНИКОМ ПІД ЧАС ВИКОНАННЯ РОБОТИ ДИСТАНЦІЙНО
}

В умовах сучасних трансформаційних процесів, що відбуваються у соціальній та економічній сферах, особливої актуальності набувають питання правового регулювання атипової форми зайнятості - виконання роботи дистанційно (на дому). Дистанційна робота $€$ прийнятною для працівника i роботодавця як за звичайних обставин, так і в умовах певних кризових чи нетипових ситуацій (наприклад, в умовах уведення карантинних обмежень на території України у зв'язку з пандемією COVID-19).

Передумовою формування атипових відносин зайнятості між працівником та роботодавцем слід уважати вираження волі обох щодо укладення трудового договору про виконання роботи дистанційно (на дому). оскільки, відповідно до положень Закону України «Про зайнятість населення». «вільно вибрана зайнятість - реалізація права громадянина вільно вибирати вид діяльності, не заборонений законом (зокрема, такий, що не пов'язаний із виконанням оплачуваної роботи), а також професію та місце роботи відповідно до своїх здібностей і потреб».

Багато хто з дослідників у галузі трудового права зауважував на важливості регламентації процедури укладення трудового договору 3 працівниками, що виконують роботу дистанційно (на дому). Так, О. Почанська розглядала можливості застосування електронного документообігу під час укладення трудового договору з надомним працівни- ком. Електронний документ, на думку дослідниці, створений за допомогою засобів автоматизації документообігу, підписаний електронним цифровим підписом і збережений у системі у вигляді файлу відповідного формату, значно спрощує роботу з великими обсягами інформаціі. I природно, що електронний вигляд документів накладає на документообіг певні вимоги. Надання надомним працівникам права вибору зовнішнього виразу форми трудового договору зможе значно поліпшити їм виконання їхніх трудових обов'язків i забезпечить надомникам можливість працювати в різних містах нашої країни [1, с. 33]. М.I. Наньєва, своєю чергою, акцентувала увагу на такому: наявного сьогодні законодавчого регулювання недостатньо для регулювання нових форм трудових відносин, зокрема щодо укладення трудового договору 3 дистанційними працівниками. Необхідно у чинному Кодексі законів про працю, у проєкті Трудового кодексу України надати визначення поняття «дистанційний працівник» та закріпити порядок укладення трудового договору 3 дистанційними працівниками: зазначити, у якій формі може укладатися такий вид трудового договору; чи можливе укладення трудового договору шляхом обміну електронними документами; які саме документи необхідні для укладення трудового договору 3 дистанційними працівниками; які вимоги ставляться до дистанційних працівників під час укладання трудового договору; чи можливе, 
наприклад, укладення трудового договору з дистанційними працівниками за результатами конкурсу. Беззаперечною $€$ нагальна необхідність законодавчого врегулювання даного питання, а саме порядку укладення трудового договору з дистанційними працівниками з урахуванням особливостей соціального захисту такого роду працівників, становлення гарантій та вимог до працівників та роботодавців [2, с. 108].

Метою статті є аналіз чинного законодавства України щодо порядку укладення трудового договору з надомними працівниками (працівниками, що виконують роботу дистанційно) та характеристика його особливостей.

Відповідно до статті 3 Закону України «Про зайнятість населення», кожен має право на вільно вибрану зайнятість. Зайнятість населення забезпечується шляхом установлення відносин, що регламентуються трудовими договорами (контрактами), провадження підприємницької та інших видів діяльності, не заборонених законом.

Статтею 5 цього ж Закону встановлено гарантії у сфері зайнятості населення, до яких відноситься вільний вибір місця застосування праці та виду діяльності, вільний вибір або зміна професіі, що означає: кожен має право на вільний вибір місця, виду діяльності та роду занять, яке забезпечується державою шляхом створення правових, організаційних та економічних умов для такого вибору.

Реалізація права на вибір місця, виду діяльності та роду занять здійснюється шляхом самостійного забезпечення особою своєї зайнятості чи звернення 3 метою працевлаштування до роботодавця або за сприяння центрального органу виконавчої влади, що реалізує державну політику у сфері зайнятості населення та трудової міграції, чи суб'єкта господарювання, який надає послуги з посередництва у працевлаштуванні (стаття 6 Закону України «Про зайнятість населення»).

Отже, враховуючи зазначені вище положення законодавства щодо зайня- тості населення, слід уважати державну гарантію на вільний вибір місця застосування праці та виду діяльності, вільний вибір або зміну професії наданням права роботодавцю та працівнику самостійно вибрати місце виконання роботи під час укладення трудового договору, оскільки, як зазначають деякі науковці, термін «гарантія» визначається через категоріі «умови», «засоби» i «способи», адже одні гарантії (економічні, політичні, ідеологічні) можна вважати умовами здійснення прав, свобод та інтересів людини, інші гарантії (юридичні) доцільно вважати засобами та способами захисту прав, свобод та інтересів людини [3, с. 10], у тому числі й трудових прав.

Трудовий договір $€$ центральним інститутом трудового законодавства та науки трудового права. Його важливість полягає, насамперед, у тому, що виникнення й існування трудових правовідносин, які $€$ ядром предмета трудового права, закон пов'язує з укладенням працівником i роботодавцем трудового договору [3, с. 77].

За своєю правовою природою трудовий договір, на нашу думку, виступає не лише документом, що регламентує відносини між працівником та роботодавцем, а юридичним фактом у результаті якого виникають зазначені відносини. Такої ж думки притримується й низка інших науковців [4-6].

На думку А.С. Ділігул, під час оформлення такого виду дистанційної зайнятості, як надомна праця, працівнику обов'язково слід укладати трудовий договір, оскільки він відіграє стабілізуючу роль у поєднанні інтересів найманих працівників та роботодавців із поєднанням у собі функції інструмента в наданні та забезпеченні соціального захисту найманих працівників [7, с. 8].

Також слід зазначити, що аналіз національного законодавства, що регулює питання виконання роботи дистанційно, у тому числі норм Кодексу законів про працю та Положення про умови праці надомних працівників, дасть нам 
змогу виявити певні особливості укладення трудового договору з надомними працівниками.

Статтею 21 Кодексу законів про працю визначено поняття трудового договору: трудовим договором $€$ угода між працівником і власником підприємства, установи, організації або уповноваженим ним органом чи фізичною особою, за якою працівник зобов'язується виконувати роботу, визначену цією угодою, а власник підприємства, установи, організації або уповноважений ним орган чи фізична особа зобов'язується виплачувати працівникові заробітну плату і забезпечувати умови праці, необхідні для виконання роботи, передбачені законодавством про працю, колективним договором і угодою сторін.

Щодо форми укладення трудового договору, то законодавство про працю визначає, що трудовий договір укладається, як правило, у письмовій формі. Додержання письмової форми $€$ обов'язковим: 1) за організованого набору працівників; 2) під час укладення трудового договору про роботу в районах 3 особливими природними географічними і геологічними умовами та умовами підвищеного ризику для здоров'я; 3) під час укладення контракту; 4) у разі коли працівник наполягає на укладенні трудового договору у письмовій формі; 5) під час укладення трудового договору 3 неповнолітнім (стаття 187 цього Кодексу); 6) під час укладення трудового договору з фізич-

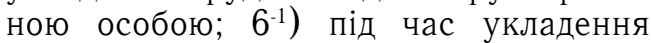
трудового договору про дистанційну (надомну) роботу; 7) в інших випадках, передбачених законодавством України (стаття 24 Кодексу законів про працю).

Так, убачається, що однією з особливостей укладення трудового договору між працівником та роботодавцем про дистанційну (надомну) роботу слід уважати застосування до нього положень про обов'язковість письмової форми.

Письмова форма трудового договору в сучасних умовах економічної нестабільності є найбільш оптимальною, як зазначає Б.А. Римар. Особливо їі значення збільшується зі зростанням договірного регулювання праці, з розширенням прав підприємств як у регулюванні власне трудових відносин, так і відносин щодо додаткового соціального забезпечення працівників [8, с. 504].

Слід зазначити, що аналіз норм Кодексу законів про працю дає змогу виявити відсутність закріплення послідовності процедури укладення трудового договору у письмовій формі, однак на підставі норм статей 21-26 можна стверджувати, що укладення трудового договору у письмовій формі означає низку дій: волевиявлення сторін трудового договору (з боку працівника це може бути оформлення заяви про прийняття на роботу, з боку роботодавця - іiі погодження та видання відповідного наказу); укладення угоди між працівником і власником підприємства, установи, організації або уповноваженим ним органом чи фізичною особою, за якою працівник зобов'язується виконувати роботу, визначену цією угодою, а власник підприємства, установи, організації або уповноважений ним орган чи фізична особа зобов'язується виплачувати працівникові заробітну плату і забезпечувати умови праці, необхідні для виконання роботи, передбачені законодавством про працю, колективним договором і угодою сторін.

Убачається, що трудовий договір отримує форму документу. Деякими дослідниками розглядається можливість закріпити в законодавстві на рівні з письмовою формою трудового договору електронну.

Електронний трудовий договір - це угода між працівником та роботодавцем, зміст якої закріплений за допомогою цифрової інформації у вигляді електронного документа, аудіо- або відеозапису 3 обов'язковим посвідченням, удосконаленим електронним цифровим підписом із боку працівника та роботодавця. Запропоноване визначення характеризує основні ознаки класичного розуміння трудового договору, а також акумулює ті додаткові 
обов'язкові, на думку А.Ю. Бурчак, О.С. Почанської, М.С. Трофименко, ознаки, що дають змогу розмежовувати договори, укладені в усній чи письмовій формі, від договорів, укладених в електронній формі $[9$, с. 88].

На нашу думку, електронна форма трудового договору нарівні 3 письмовою має право на існування та іï відповідне закріплення у трудовому законодавстві, у тому числі вона може бути застосована по відношенню до закріплення трудових відносин надомних працівників.

Щодо інших особливостей порядку укладення трудового договору 3 працівником, що виконує роботу дистанційно, то звертають на себе увагу норми Розділу II Положення про умови праці надомних працівників, затверджене Державним комітетом СРСР із питань праці та соціальних питань Секретаріату ВЦРПС від 29 вересня 1981 р. № 275/17-99 (що є досі чинним та застосовується для регулювання трудових відносин надомників), яке визначає, що переважне право на укладення трудового договору про роботу на дому надається: жінкам, які мають дітей у віці до 15 років; інвалідам і пенсіонерам (незалежно від виду призначеної пенсії); особам, які досягли пенсійного віку, але не одержують пенсію; особам зі зниженою працездатністю, яким у встановленому порядку рекомендована праця в надомних умовах; особам, які здійснюють догляд за інвалідами або членами сім'ї, що тривало хворіють, які за станом здоров'я потребують догляду; особам, зайнятим на роботах із сезонним характером виробництва (у міжсезонний період), а також навчаються в очних навчальних закладах; особам, які з об'єктивних причин не можуть бути зайняті безпосередньо на виробництві в даній місцевості (наприклад, у районах і місцевостях, що мають вільні трудові ресурси). Особи, які володіють майстерністю виготовлення виробів народних художніх промислів, сувенірних виробів або оригінальної упаковки для них, можуть бути прийняті на роботу як надомники незалежно від роду їхньої діяльності i роботи на інших підприємствах. При цьому обмеження, встановлені законодавством про сумісництво, на них не поширюються.

Уважаємо зазначене коло осіб, яких зазначене Положення визначає як потенційних надомників, досить обмеженим, оскільки наявність глобалізаційних та євроінтеграційних процесів, наявних в українському сучасному суспільстві, значно трансформувала зміст економічних та соціальних відносин із часу прийняття цього Положення (1981 р.).

Однак норми п.п. 6-8 Розділу II Положення про умови праці надомних працівників, визначають такі умови укладення трудових договорів iз надомниками: особи, які бажають вступити на роботу як надомники, зобов'язані пред'явити адміністрації паспорт, а раніше працювали - i трудову книжку. Підлітки у віці від 15 до 16 років пред’являють копію свідоцтва про народження; трудовий договір про роботу на дому укладається, як правило, у письмовій формі. У трудовому договорі з надомником повинні бути найбільш повно викладені як основні, так і додаткові умови, що визначають взаємні зобов'язання сторін. Прийом на роботу як надомника оформляється наказом (розпорядженням) адміністрації підприємства; на надомників, що раніше не працювали в громадському виробництві, заводяться трудові книжки після здачі ними першого виконаного завдання. У такому ж порядку вносяться записи в трудові книжки тих надомників, які мають ці книжки.

$\mathrm{y}$ межах регулювання дистанційної роботи нормами зазначеного Положення слід визначити, що потрібно віднести до основних та додаткових умов трудового договору із надомником. Розділ III визначає положення щодо організації та умов праці надомника, організація в надомних умовах трудових процесів допускається тільки для осіб, які мають необхідні житлово-побутові 
умови, а також практичні навички або можуть бути навчені цим навичкам для виконання певних робіт. Обстеження житлово-побутових умов громадян, які виявили бажання працювати на дому, проводиться адміністрацією підприємства, що застосовує надомну працю, за участю представників комітету профспілки (ФЗМК), а у відповідних випадках - і представників санітарного та пожежного нагляду.

Розділ IV Положення про умови праці надомних працівників визначає умови оплати та соціального страхування таких працівників. Додатково до його норм слід урахувати і зміст статті 60 Кодексу законів про працю, що виконання дистанційної (надомної) роботи не тягне за собою будь-яких обмежень обсягу трудових прав працівників. При цьому якщо працівник i роботодавець письмово не домовилися про інше, дистанційна (надомна) робота передбачає оплату праці в повному обсязі та в строки, визначені діючим трудовим договором.

Також до основних умов, що мають бути відображені у трудовому договорі 3 надомним працівником, слід віднести включення положень про час відпочинку, у тому числі відпустки. Статтею 75 Кодексу законів про працю встановлено, що щорічна основна відпустка надається працівникам тривалістю не менш як 24 календарних дні за відпрацьований робочий рік, який відлічується зі дня укладення трудового договору. Особам віком до вісімнадцяти років надається щорічна основна відпустка тривалістю 31 календарний день. Для деяких категорій працівників законодавством України може бути передбачена інша тривалість щорічної основної відпустки. При цьому тривалість їхньої відпустки не може бути меншою за передбачену частиною першою цієї статті. У пункті 18 Положення про умови праці надомних працівників установлено інший строк щорічної відпустки - 15 робочих днів, якщо вони, відповідно до законодавства, не мають права на щорічну осно- вну відпустку більшої тривалості. Ураховуючи положення статті 60 Кодексу законів про працю про те, що виконання дистанційної (надомної) роботи не тягне за собою будь-яких обмежень обсягу трудових прав працівників, уважаємо неприйнятним застосування норм зазначеного Положення під час визначення у трудовому договорі надомного працівника строку щорічної відпустки, оскільки вони є обмежувальними. Наявність зазначеної колізї в правовому регулюванні часу відпочинку надомних працівників має подвійний характер: негативний - для працівника та позитивний - для роботодавця.

3 огляду на вищезазначене, вважаємо, що норми Положення про умови праці надомних працівників $€$ застарілими та не відповідають сьогоденню, тому його чинність нині під великим питанням, особливо враховуючи останні зміни щодо правового регулювання дистанційної роботи, внесені до Кодексу законів про працю Законом № 540-IX від 30 березня 2020 р. Уважаємо, що правове регулювання дистанційної роботи загалом та порядку укладення трудових договорів із працівниками, що виконують роботу дистанційно, є звуженим та потребує подальшого вдосконалення.

Такої ж думки притримуються й інші науковці. Зокрема, на думку H.M. Вапнярчук, до основних напрямів оптимізації правового регулювання дистанційної зайнятості в Україні слід віднести такі: у Трудовому кодексі України (проєкт) закріпити главу про дистанційних працівників, в якій передбачити: порядок укладення трудового договору; положення, відповідно до якого роботодавець зобов'язаний забезпечити дотримання працівником вимог охорони праці та санітарно-гігієнічних норм; положення, згідно з яким оплата здійснюється не за результат роботи, а за фактично витрачений час відповідно до встановлених на підприємстві загальних норм виробітку з відповідною оплатою робочого часу; 
положення, згідно 3 яким норми на сумісництво та суміщення поширюються на дистанційних працівників, якщо працівник комбінує роботу за місцем проживання та роботу в приміщенні підприємства; положення «у разі використання дистанційної зайнятості роботодавець зобов'язаний забезпечити первинну профспілкову організацію необхідним обладнанням для участі дистанційних працівників у діяльності останньої» [10, с. 103].

Подальше вдосконалення трудового законодавства та сприяння законодавчій визначеності у питанні укладення трудових договорів із працівниками, що виконують роботу дистанційно, відповідатимуть сучасним умовам соціальноекономічного розвитку України.

Статтю присвячено актуальним питанням укладення трудового договору з працівниками, щзо виконують роботу дистаниійно. Автор указуе на актуальність вибраної теми дослідження, оскільки дистаниійна робота є прийнятною для працівника $i$ для роботодавияя як за звичайних обставин, так $i$ в умовах певних кризових чи нетипових ситуаціях (наприклад, в умовах уведення карантинних обменень на територіі України у зв'язку з пандемією COVID-19). Передумовою формування атипових відносин зайнятості між працівником та роботодавцеем, на думку автора, сліо уважати вираження волі обох щодо укладення трудового договору про виконання роботи дистаниійно (на дому).

У ході дослідження доктринальних підходів до визначення форми трудового договору автор звертає увагу на те, щзо деякі науковизі визначають можливість вибору електронної форми укладення трудового договору з працівниками, що праиюють дистанційно. Автор погоджується, що електронна форма трудового договору нарівні з письмовою має право на існування та ї відповідне закріплення у трудовому зако- нодавстві, у тому числі вона може бути застосована по відношенню до закріплення трудових відносин надомних працівників.

Автором проаналізовано чинне трудове законодавство, що визначає поняття та форму трудового договору під час дистанційної роботи, особливості визначення його умов, що дало змогу зробити висновки щодо того, що правове регулювання дистаниійної роботи загалом та порядку укладення трудових договорів із працівниками, котрі виконують роботу дистаниійно, є звуженим ma потребуе подальшого вдосконалення. Невідповідність трудового законодавства в частині укладення трудових договорів із працівникам, що виконують роботу дистанційно, трансформаційним процесам, які відбуваються у суспільстві, є не лише проблемою для як для працівника та роботодавия, так $і$ для держави у изілому, оскільки потенційно впливає на ї̈ економічний та соціальний розвиток.

Ключові слова: трудовий договір, трудове законодавство, зайнятість населення, атипова форма зайнятості, дистанційна робота.

\section{Kuznetsova M. Current issues} of concluding an employment contract with an employee when performing work remote

The article is devoted to the topical issues of concluding an employment contract with employees who work remotely. The author points out the relevance of the chosen research topic, as remote work is acceptable for both the employee and the employer both under normal circumstances and in certain crisis or atypical situations (for example, in the introduction of quarantine restrictions in Ukraine in connection with the COVID-19 pandemic). According to the author, the expression of the will of both to conclude an employment contract for remote work (at home) should 


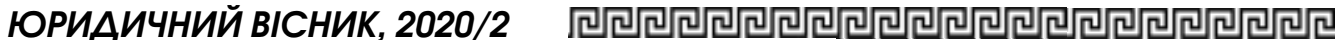

be considered a prerequisite for the formation of atypical employment relations between the employee and the employer.

In the study of doctrinal approaches to determining the form of employment contract, the author pays attention to the fact that some scholars determine the possibility of choosing an electronic form of employment contract with employees working remotely. The author agrees that the electronic form of employment contract, along with written, has the right to exist and its appropriate enshrinement in labor law, including it can be used in relation to the consolidation of employment of home workers.

The author analyzed the current labor legislation, which defines the concept and form of employment contract for telework, especially the definition of its conditions, which led to the conclusion that the legal regulation of telework in general and the procedure for concluding employment contracts with employees working remotely. narrowed and needs further improvement. Inconsistency of labor legislation in terms of concluding employment contracts with employees who work remotely, the transformation processes taking place in society, is not only a problem for both the employee and the employer, and for the state as a whole, as it potentially affects its economic and social development.

Key words: employment contract, labor legislation, employment, atypical form of employment, remote work.

\section{Література}

1. Почанська О. Електронний документообіг при укладенні трудового договору з надомними працівниками: правовий аспект. Підприємництво, господарство $i$ право. 2016. №. 4. С. 30-33.

2. Наньєва М.I. Укладення трудового договору з дистанційними пращівниками за законодавством України. Науковий вісник Міжнародного гуманітарного університету. Серія «Юриспруденція». 2019. № 38. C. 106-108. DOI : https://doi.org/ 10.32841 / 2307-1745.2019.38.25.

3. Мельник К.Ю., Бабенко А.О. Проблеми юридичних гарантій трудових прав працівників при укладенні, зміні та розірванні трудового договору. Харків : Харків. нац. ун-т внутр. справ, 2016. 240 c.

4. Андронова B.А. Юридичні факти у трудовому праві України : автореф. дис. ... канд. юрид. наук : 12.00.05 - трудове право; право соціального забезпечення. Oдеca, 2014. 16 c.

5. Солодовник Л.В. Юридичні факти у трудовому праві України : дис. ... канд. юрид. наук : 12.00 .05 - трудове право; право сочіального забезпечення. Харків, 2004. $191 \mathrm{c}$

6. Пилипенко П.Д. Підстави виникнення індивідуальних трудових правовідносин. Київ : Знання, 2003. С. 38.

7. Ділігул А.С. Правове регулювання надомної праці за трудовим законодавством України. : автореф. дис. ... канд. юрид. наук : 12.00.05 - трудове право; право соціального забезпечення ; $М В C$ України, Харк. наи. ун-т внутр. справ. Харків, 2018. 26 c.

8. Римар Б.А. Форма трудового договору у сучасному законодавстві про праию. Правові та інституційні механізми забезпечення розвитку держави та права в умовах євроінтеграції : матеріали Міжнародної науково-практичної конференції, м. Одеса, 20 травня 2016 р. Одеса : Юридична rimepamypa, 2016. C. 503-505.

9. Бурчак А.Ю., Почанська О.С., Трофименко М.С. Електронна форма трудового договору в контексті реформування законодавства про працю. Підприємництво, господарство і право. 2019. № 1. С. 84-89.

10. Вапнярчук Н.М. Дистанційна зайнятість: проблеми правового регулювання. Право та інновації. 2016. №. 1. С. 101-106. 